Asian J. Med. Biol. Res. 2016, 2 (1), 74-81; doi: 10.3329/ajmbr.v2i1.27572

\author{
Asian Journal of \\ Medical and Biological Research \\ ISSN 2411-4472 (Print) 2412-5571 (Online) \\ www.ebupress.com/journal/ajmbr
}

\title{
Article \\ Mitigation of salt stress in rice plant at germination stage by using methyl jasmonate
}

Sakil Mahmud*, Shayla Sharmin, Bishan Lal Das Chowdhury, Mohammad Anowar Hossain and Muhammad Javidul Haque Bhuiyan

Department of Biochemistry and Molecular Biology, Bangladesh Agricultural University, Mymensingh, Bangladesh

${ }^{*}$ Corresponding author: Sakil Mahmud, Department of Biochemistry and Molecular Biology, Bangladesh Agricultural University, Mymensingh, Bangladesh. E-mail: sakilbmb@bau.edu.bd

Received: 07 March 2016/Accepted: 22 March 2016/Published: 31 March 2016

\begin{abstract}
To explore the possibility of using methyl jasmonate (MeJA) for alleviation of salt stress, the present study was conducted where six rice varieties (BRRI dhan31, BRRI dhan46, Gota, Kajalsail, Pokkali and Pengek) were grown in non saline $\left(0 \mathrm{dSm}^{-1}\right)$, saline $\left(12 \mathrm{dSm}^{-1}\right)$, saline $\left(12 \mathrm{dSm}^{-1}\right)+10 \mu \mathrm{M} \mathrm{MeJA}$ and saline $(12$ $\left.\mathrm{dSm}^{-1}\right)+20 \mu \mathrm{M}$ MeJA conditions at germination stage (till the 9 days). MeJA was applied by imbibing seeds in it for 24 hours. To evaluate the effect of MeJA on saline stressed plant at germination stage, change in growth parameters namely germination percentage, shoot and root length, fresh and dry wt. of shoot, fresh and dry wt. of root and biochemical component- activity of alpha-amylase were monitored. Salinity had a minimum effect on final germination percentage (FGP) of rice varieties, but delayed in attaining it. MeJA had least positive effect. Salinity significantly reduced the shoot and root length, fresh and dry weight of all the varieties. MeJA had more decreasing effect in susceptible varieties while increasing effect in moderately tolerant and tolerant. Activity of alpha-amylase in germinated seed varied from $0.051 \mathrm{mg}$ to $0111 \mathrm{mg}$ mal./mg tissue. At $12 \mathrm{dSm}^{-1}$ salinity, susceptible and moderately tolerant varieties showed significant reduction but tolerant showed significant increase. MeJA intensified the negative effect further in susceptible varieties. In tolerant and moderately tolerant varieties, increment in activity took place and $10 \mu \mathrm{M}$ had a better effect over $20 \mu \mathrm{M}$ MeJA.
\end{abstract}

Keywords: methyl jasmonate; rice; growth parameter; alpha- amylase

\section{Introduction}

Salinity is one of the most severe problems of agriculture worldwide. In the global context approximately $20 \%$ of the irrigated lands in the world are presumably affected by soil salinization (Yeo 1999). Coastal salinity and accumulation of salts in the irrigated land primarily decrease crop yield. In Bangladesh, coastal area covers about $20 \%$ of the country and over thirty percent of the net cultivable area. Out of 2.85 million hectares of the coastal and offshore areas, about 1.5 million hectares coastal and offshore land is affected by different degrees of salinity. So, for growing crops in those areas, innovative and commercially feasible alternative need to be explored.

Rice (Oryza sativa) is the most important and extensively grown food crop and leading cereal in the world including Bangladesh. It is one of the most widely grown crops in coastal areas as well and frequently inundated with saline seawater during high tidal period. Sudden up-surging of saline water demands necessary measures to counteract the saline stress for a short period. Post-application with exogenous jasmonic acid (JA) can ameliorate salt-stressed rice seedlings (Kang et al., 2005).

Abiotic stress leads to a series of morphological, physiological, biochemical and molecular changes that adversely affect plant growth and productivity. Rice varieties show a great variation in germination due to salinity effect (Sharmin 2012; Khan et al., 1997). Several reports suggest that saline condition causes delayed germination (Prado et al., 1995) by reducing hydrolytic activities (Ashraf et al., 2002). Mobilization of seed 
reserves, which occurs during early seed germination, is crucial. Alpha amylase plays an important role in starch degradation in germinating seeds and mobilization of reserved material required for the growth of young seedling (Chen et al., 2006).

Methyl jasmonate (MeJA) and jasmonic acid (JA) are collectively referred to as jasmonate and are important cellular regulators which are involved in diverse developmental process such as germination, root growth, fertility, fruit ripening and senescence (Creelman and Rao 2002; Westernack and House 2002).

The response of plants to salt stress depends on multiple factors, but phytohormones are thought to be among the most important endogenous substances involved in the tolerance or susceptibility. Exogenous JA application after salt treatment may change the balance of endogenous hormones, such as ABA, which contribute in protection mechanisms against salt stress (Kang et al., 2005). Pre-treatment with JA reduced the inhibitory effect of high salt concentrations on growth and photosynthesis (Tsonev et al., 1998; Yoon et al., 2009). Exogenously applied jasmonates elicit several different physiological responses to stress and therefore increase plant resistance (Walia et al., 2007; Ding et al., 2002).

It should be noted that there is a lack of studies on the ameliorative effect of jasmonate on crop production under saline conditions and additional studies on this topic are warranted. The aim of the current study was to evaluate the role of MeJA in counteracting salinity stress in rice plant at germination stage. The effect of MeJA on alphaamylase activity as well as on growth parameters such as germination percentage, shoot and root length, fresh and dry wt. of shoot and fresh and dry wt. of root in salt stressed rice plant at their germination stage was monitored.

\section{Materials and Methods}

The experiment was conducted at the laboratory of the Department of Biochemistry and Molecular Biology, Bangladesh Agricultural University, Mymensingh, during the period from January to November, 2014.

\subsection{Plant material}

Two high yielding varieties (BRRI dhan31 and BRRI dhan46) and four local varieties (Pokkali, Pengek, Kajalsail, Gota) were used in the experiment. Among the varieties, BRRI dhan31 and BRRI dhan46 are susceptible, Kajalsail and Gota are moderately tolerant and Pokkali and Pengek are tolerant to salt stress as reported by Bangladesh Rice Research Institute (BRRI).

\subsection{Treatments application}

Salinity $\left(12 \mathrm{dSm}^{-1}\right)$ combined with two levels of methyl jasmonate $(10 \mu \mathrm{M}$ and $20 \mu \mathrm{M})$ were applied. Rice (Oryza sativa) seeds were sterilized with $2.5 \%$ sodium hypochlorite for $15 \mathrm{~min}$ and washed thoroughly with distilled water. These seeds were then placed in deep petri dishes containing filter papers. Each petri dish contained 25 rice seeds. In case of control $\left(\mathrm{T}_{0}\right), 10 \mathrm{ml}$ of distilled water was added to the petri dish. To develop salinity stress $\mathrm{T}_{1}\left(\mathrm{EC}=12 \mathrm{dSm}^{-1}\right)$, filter papers were moistened with $10 \mathrm{ml}$ of salt solutions. In case of treatments, $\mathrm{T}_{2}$ and $\mathrm{T}_{3}$, seeds were imbibed in presence of methyl jasmonate for $24 \mathrm{~h}$ before placement to the petri dishes. Properly imbibed seeds were placed in petri dishes containing moistened filter papers to allow them to germinate. Each treatment was performed three times. The seeds were allowed to germinate at around $30^{\circ} \mathrm{C}$ in the dark for 9 days.

\subsection{Determination of growth parameters}

\subsubsection{Germination percentage}

The number of sprouted and germinated seeds was counted daily commencing from $4^{\text {th }}$ day till the $9^{\text {th }}$. After 9 days, final count was done and germination percentage of each day was calculated by the following formula: Germination Percentage $(\% \mathrm{GE})=($ Total number of seeds germinated/Total number of seeds taken for germination) $\times 100$.

\subsubsection{Shoot and root length}

Shoot and root length of five randomly selected seedlings from each replication were measured daily from $5^{\text {th }}$ to $9^{\text {th }}$ days withdrawing the seedlings from the petri dish.

\subsubsection{Fresh and dry weight of shoot and root}

Fresh weight of shoot and root were determined immediately after harvest. Dry weight was recorded by drying the sample in an oven at $70^{\circ} \mathrm{C}$ till attained a constant weight. 


\subsubsection{Determination of alpha-amylase activity}

Alpha-amylase activity was determined spectrophotometrically by using 3, 5 dinitrosalicylic acid (DNSA) following the procedure of Bernfeld (1955). After 9 days of salt treatment, germinating seeds were used for the determination of amylase activity. Growing embryonic tissues (scutellum, roots, and shoots) and seed coat were carefully removed from rice seeds. Endosperm tissues were used for amylase extraction. Five hundred milligrams endosperm tissue was crushed with $10 \mathrm{ml}$ of $0.02 \mathrm{M}$ phosphate buffer at $\mathrm{pH}$ 6.0. The homogenate was centrifuged at $2500 \mathrm{rpm}$ for 20 minutes. The supernatant was used to determine the enzyme activity.

\subsection{Statistical analysis}

The experiment were arranged in a completely randomized design with three replications and the data collected and calculated were analyzed using MSTAT - C computer programs and comparison of means were tested for significance using least significant difference (LSD) test, at 0.01 level of probability.

\section{Results}

\subsection{Germination percentage}

Salinity imposed a negligible reduction in all rice varieties from $4^{\text {th }}$ to $9^{\text {th }}$ days (Table 1 ). In this study, the effect of salinity on final germination percentage (FGP) of rice seeds was not pronounced. Under control condition, two susceptible varieties showed $100 \%$ and $96 \%$ germination at $4^{\text {th }}$ day respectively. In each treatment, the maximum germination rate attained by a variety was considered as final germination percentage (FGP) and it was $100 \%$ in case of both BRRI dhan31 and BRRI dhan46. Under saline condition, BRRI dhan31 showed a slight reduction (96\%) whereas BRRI dhan 46 had the same value compared to the control plants.

Exogenously applied MeJA had negligible effect. When the rice seeds of BRRI dhan31was treated with $10 \mu \mathrm{M}$ and $20 \mu \mathrm{M}$ MeJA and were grown in saline condition, the observed germination percentage (\%GE) were $98 \%$ and $96 \%$ respectively. Under similar condition, BRRI dhan46 had 100\% and $96 \%$ respectively. Moderately tolerant varieties, Gota and Kajalsail showed similar FGP (100) at $9^{\text {th }}$ day under control condition. Salinity caused slight reduction in FGP (96 and 98). MeJA treatment had positive effect and FGP reached to 100\% on MeJA treatment in case of both the varieties as well as treatments $(10 \mu \mathrm{M}$ and $20 \mu \mathrm{M})$. Tolerant varieties, Pokkali and Pengek had 100\% FGP under control condition. However, under saline condition, Pokkali showed a reduction $(96 \%)$ compared to that of control at $9^{\text {th }}$ day. Both varieties attained a maximum germination percentage $(100 \%)$ at $10 \mu \mathrm{M}$ MeJA condition. At $20 \mu \mathrm{M}$ MeJA treatment, Pokkali maintained its optimum germination rate but reduction (98\%) was noticed in Pengek.

\subsection{Shoot length}

It appeared that saline conditions significantly reduced the shoot length of all varieties (Figure 1). At the salt concentration, reduction was ranged from $25.96 \%$ to $49.14 \%$. In applying MeJA, reduction was further enhanced in the susceptible varieties and the maximum reduction ( 3 times) was shown by BRRI dhan 46 with the application of $20 \mu \mathrm{M}$ MeJA. In case of moderately tolerant and tolerant varieties, positive effect was monitored and increase rate ranged from $5.61 \%$ to $19.52 \%$ in moderately tolerant while $0.929 \%$ to $12.21 \%$ in tolerant varieties.

\subsection{Root length}

The root length of all the rice varieties was significantly reduced in saline condition and the reduction rate ranged from $37.51 \%$ to $52.63 \%$ (Figure 2). On applying MeJA, further reduction was noticed in the susceptible varieties and the reduction rate ranged from $8.36 \%$ to $41.16 \%$. In case of moderately tolerant and tolerant varieties, reduction due to salinity was mitigated and root length increase rate ranged from $4.51 \%$ to $6.13 \%$ in moderately tolerant while $2.94 \%$ to $18.91 \%$ in tolerant varieties. Better performance was observed in Pokkali on applying $20 \mu \mathrm{M}$ MeJA.

\subsection{Fresh and dry weight of shoot}

Shoot fresh wt. and dry wt. was inversely proportional to salinity i.e. decrease in saline condition (Table 2). Reduction rate ranged from $23.81 \%$ to $59.09 \%$ in case of fresh wt. while $16.67 \%$ to $61.11 \%$ of dry wt. On applying MeJA, both fresh and dry wt. were decreased in susceptible varieties which ranged from $4.80 \%$ to $37.63 \%$ in case of fresh wt. fresh wt. while $12.5 \%$ to $38.10 \%$ of dry wt. compared to saline condition. In case of moderately tolerant and tolerant varieties, both fresh and dry wt. was further enhanced upon applying MeJA. Maximum increase of fresh wt. was observed in Pengek upon $20 \mu \mathrm{M}$ MeJA application while in case of dry wt., both tolerant varieties got maximum increase. 
Asian J. Med. Biol. Res. 2016, 2 (1)

Table 1. Changes in germination percentage of rice seed under salt stress and MeJA application.

\begin{tabular}{|c|c|c|c|c|c|c|}
\hline \multirow{2}{*}{\multicolumn{2}{|c|}{ Variety }} & \multirow{2}{*}{$\begin{array}{c}\text { Days of } \\
\text { germination }\end{array}$} & \multicolumn{3}{|c|}{ Germination percent (\%GE) } & \multirow[b]{2}{*}{$\mathbf{T}_{3}$} \\
\hline & & & $\mathbf{T}_{\mathbf{0}}$ & $T_{1}$ & $\mathbf{T}_{2}$ & \\
\hline \multirow{12}{*}{ 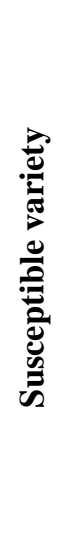 } & BRRI dhan31 & $4^{\text {th }}$ day & 100 & 88 & 96 & 96 \\
\hline & & $5^{\text {th }}$ day & 100 & 92 & 98 & 96 \\
\hline & & $6^{\text {th }}$ day & 100 & 96 & 98 & 96 \\
\hline & & $7^{\text {th }}$ day & 100 & 96 & 98 & 96 \\
\hline & & $8^{\text {th }}$ day & 100 & 96 & 98 & 96 \\
\hline & & $9^{\text {th }}$ day & 100 & 96 & 98 & 96 \\
\hline & BRRI & $4^{\text {th }}$ day & 96 & 96 & 92 & 88 \\
\hline & dhan 46 & $5^{\text {th }}$ day & 100 & 100 & 96 & 96 \\
\hline & & $6^{\text {th }}$ day & 100 & 100 & 100 & 96 \\
\hline & & $7^{\text {th }}$ day & 100 & 100 & 100 & 96 \\
\hline & & $8^{\text {th }}$ day & 100 & 100 & 100 & 96 \\
\hline & & $9^{\text {th }}$ day & 100 & 100 & 100 & 96 \\
\hline \multirow{12}{*}{ 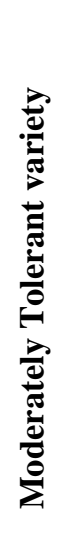 } & & $4^{\text {th }}$ day & 96 & 92 & 100 & 100 \\
\hline & Kajalsail & $5^{\text {th }}$ day & 100 & 96 & 100 & 100 \\
\hline & & $6^{\text {th }}$ day & 100 & 96 & 100 & 100 \\
\hline & & $7^{\text {th }}$ day & 100 & 96 & 100 & 100 \\
\hline & & $8^{\text {th }}$ day & 100 & 96 & 100 & 100 \\
\hline & & $9^{\text {th }}$ day & 100 & 96 & 100 & 100 \\
\hline & & $4^{\text {th }}$ day & 100 & 92 & 100 & 100 \\
\hline & Gota & $5^{\text {th }}$ day & 100 & 98 & 100 & 100 \\
\hline & & $6^{\text {th }}$ day & 100 & 98 & 100 & 100 \\
\hline & & $7^{\text {th }}$ day & 100 & 98 & 100 & 100 \\
\hline & & $8^{\text {th }}$ day & 100 & 98 & 100 & 100 \\
\hline & & $9^{\text {th }}$ day & 100 & 98 & 100 & 100 \\
\hline \multirow{12}{*}{ 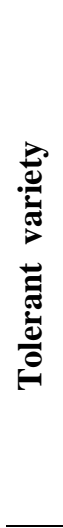 } & & $4^{\text {th }}$ day & 100 & 96 & 100 & 96 \\
\hline & Pokkali & $5^{\text {th }}$ day & 100 & 96 & 100 & 100 \\
\hline & & $6^{\text {th }}$ day & 100 & 96 & 100 & 100 \\
\hline & & $7^{\text {th }}$ day & 100 & 96 & 100 & 100 \\
\hline & & $8^{\text {th }}$ day & 100 & 96 & 100 & 100 \\
\hline & & $9^{\text {th }}$ day & 100 & 96 & 100 & 100 \\
\hline & & $4^{\text {th }}$ day & 100 & 96 & 100 & 98 \\
\hline & Pengek & $5^{\text {th }}$ day & 100 & 100 & 100 & 98 \\
\hline & & $6^{\text {th }}$ day & 100 & 100 & 100 & 98 \\
\hline & & $7^{\text {th }}$ day & 100 & 100 & 100 & 98 \\
\hline & & $8^{\text {th }}$ day & 100 & 100 & 100 & 98 \\
\hline & & $9^{\text {th }}$ day & 100 & 100 & 100 & 98 \\
\hline
\end{tabular}


Table 2. Changes in fresh weight and dry weight of shoot of rice seedlings under salt stress and MeJA application.

\begin{tabular}{|c|c|c|c|c|}
\hline \multirow{2}{*}{ Variety } & \multicolumn{4}{|c|}{ Fresh weight of shoot (g / 5 plants) } \\
\hline & $\mathbf{T}_{\mathbf{0}}$ & $\mathbf{T}_{1}$ & $\mathbf{T}_{2}$ & $\mathbf{T}_{3}$ \\
\hline BRRI dhan31 & $0.192^{\mathrm{a}}$ & $0.104^{\mathrm{b}}(-45.83)$ & $0.099 b^{c}(-4.80)$ & $0.065^{\mathrm{c}}(-37.5)$ \\
\hline BRRI dhan46 & $0.132^{\mathrm{a}}$ & $0.093^{\mathrm{b}}(-29.55)$ & $0.062^{c}(-33.33)$ & $0.058^{c}(-37.63)$ \\
\hline Kajalsail & $0.119^{\mathrm{a}}$ & $0.060^{\mathrm{b}}(-49.58)$ & $0.062^{\mathrm{b}}(+3.33)$ & $0.061^{\mathrm{b}}(+1.67)$ \\
\hline Gota & $0.147^{\mathrm{a}}$ & $0.112^{\mathrm{b}}(-23.81)$ & $0.126^{\mathrm{ab}}(+12.5)$ & $0.122^{\mathrm{b}}(+8.93)$ \\
\hline Pokkali & $0.184^{\mathrm{a}}$ & $0.086^{\mathrm{c}}(-53.26)$ & $0.107^{\mathrm{bc}}(+24.42)$ & $0.130^{\mathrm{b}}(+51.16)$ \\
\hline Pengek & $0.198^{\mathrm{a}}$ & $0.081^{\mathrm{c}}(-59.09)$ & $0.124^{\mathrm{b}}(+53.08)$ & $0.134^{\mathrm{b}}(+65.43)$ \\
\hline \multicolumn{5}{|c|}{ Dry weight of shoot (g / 5 plants) } \\
\hline BRRI dhan31 & $0.0165^{\mathrm{a}}$ & $0.0105^{\mathrm{b}}(-36.36)$ & $0.0065^{\mathrm{b}}(-38.10)$ & $0.0085^{\mathrm{b}}(-19.05)$ \\
\hline BRRI dhan46 & $0.020^{\mathrm{a}}$ & $0.012^{\mathrm{b}}(-40)$ & $0.010^{\mathrm{b}}(-16.67)$ & $0.0105^{\mathrm{b}}(-12.5)$ \\
\hline Kajalsail & $0.018^{\mathrm{a}}$ & $0.007^{\mathrm{b}}(-61.11)$ & $0.008^{\mathrm{b}}(+14.29)$ & $0.009^{\mathrm{b}}(+28.57)$ \\
\hline Gota & $0.018^{\mathrm{a}}$ & $0.015^{\mathrm{a}}(-16.67)$ & $0.016^{\mathrm{a}}(+6.67)$ & $0.017^{\mathrm{a}}(+13.33)$ \\
\hline Pokkali & $0.026^{\mathrm{a}}$ & $0.014^{\mathrm{c}}(-46.15)$ & $0.018^{b c}(+28.57)$ & $0.019^{\mathrm{b}}(+35.71)$ \\
\hline Pengek & $0.029^{\mathrm{a}}$ & $0.014^{\mathrm{c}}(-51.72)$ & $0.018^{\mathrm{b}}(+28.57)$ & $0.019^{b}(+35.71)$ \\
\hline
\end{tabular}

Figures in parenthesis of $\mathrm{T}_{1}$ were calculated as percentage based on the values in control $\left(\mathrm{T}_{0}\right)$ and figures in parenthesis of $\mathrm{T}_{2}$ and $\mathrm{T}_{3}$ were computed as percentage based on the values obtained from saline stress $\left(\mathrm{T}_{1}\right)$.

$(+)$ indicates "\%increase", (-) indicates "\%decrease". Significant differences in the treatments are shown with different letters $(\mathrm{p}<0.01)$.

Table 3. Changes in fresh weight and dry weight of root of rice seedlings under salt stress and MeJA application.

\begin{tabular}{lllll}
\hline Variety & \multicolumn{4}{c}{ Fresh weight of root $(\mathbf{g} / \mathbf{5}$ plants } \\
\cline { 2 - 5 } & $\mathbf{T}_{\mathbf{0}}$ & $\mathbf{T}_{\mathbf{1}}$ & $\mathbf{T}_{\mathbf{2}}$ & $\mathbf{T}_{\mathbf{3}}$ \\
\hline BRRI dhan31 & $0.133^{\mathrm{a}}$ & $0.083^{\mathrm{b}}(-37.59)$ & $0.074^{\mathrm{b}}(-10.84)$ & $0.067^{\mathrm{b}}(-19.27)$ \\
BRRI dhan46 & $0.142^{\mathrm{a}}$ & $0.101^{\mathrm{b}}(-28.87)$ & $0.067^{\mathrm{c}}(-33.66)$ & $0.058^{\mathrm{c}}(-42.57)$ \\
Kajalsail & $0.154^{\mathrm{a}}$ & $0.068^{\mathrm{b}}(-55.84)$ & $0.078^{\mathrm{b}}(+14.71)$ & $0.072^{\mathrm{b}}(+5.88)$ \\
Gota & $0.103^{\mathrm{a}}$ & $0.056^{\mathrm{b}}(-45.63)$ & $0.103^{\mathrm{a}}(+83.93)$ & $0.101^{\mathrm{a}}(+80.36)$ \\
Pokkali & $0.11^{\mathrm{a}}$ & $0.066^{\mathrm{b}}(-40)$ & $0.066^{\mathrm{b}}(0)$ & $0.071^{\mathrm{b}}(+7.58)$ \\
Pengek & $0.126^{\mathrm{a}}$ & $0.026^{\mathrm{c}}(-79.37)$ & $0.054^{\mathrm{b}}(+107.7)$ & $0.049^{\mathrm{b}}(+88.46)$ \\
Dry weight of root $\mathbf{( g / 5}$ plants $_{\text {BRRI dhan31 }}$ & & & \\
BRRI dhan46 & $0.016^{\mathrm{a}}$ & $0.009^{\mathrm{b}}(-43.75)$ & $0.006^{\mathrm{b}}(-33.33)$ & $0.005^{\mathrm{b}}(-44.44)$ \\
Kajalsail & $0.0165^{\mathrm{a}}$ & $0.0085^{\mathrm{b}}(-48.48)$ & $0.006^{\mathrm{b}}(-29.41)$ & $0.007^{\mathrm{b}}(-17.65)$ \\
Gota & $0.0185^{\mathrm{a}}$ & $0.007^{\mathrm{c}}(-62.16)$ & $0.013^{\mathrm{b}}(+92.86)$ & $0.008^{\mathrm{c}}(+14.29)$ \\
Pokkali & $0.020^{\mathrm{a}}$ & $0.011^{\mathrm{b}}(-45)$ & $0.014^{\mathrm{b}}(+27.27)$ & $0.012^{\mathrm{b}}(+9.09)$ \\
Pengek & $0.0145^{\mathrm{a}}$ & $0.0075^{\mathrm{b}}(-48.27)$ & $0.0089^{\mathrm{b}}(+18.67)$ & $0.0095^{\mathrm{b}}(+26.67)$ \\
\hline
\end{tabular}

Figures in parenthesis of $\mathrm{T}_{1}$ were calculated as percentage based on the values in control $\left(\mathrm{T}_{0}\right)$ and figures in parenthesis of $\mathrm{T}_{2}$ and $\mathrm{T}_{3}$ were computed as percentage based on the values obtained from saline stress $\left(\mathrm{T}_{1}\right)$.

$(+)$ indicates "\%increase", (-) indicates "\%decrease". Significant differences in the treatments are shown with different letters $(\mathrm{p}<0.01)$.

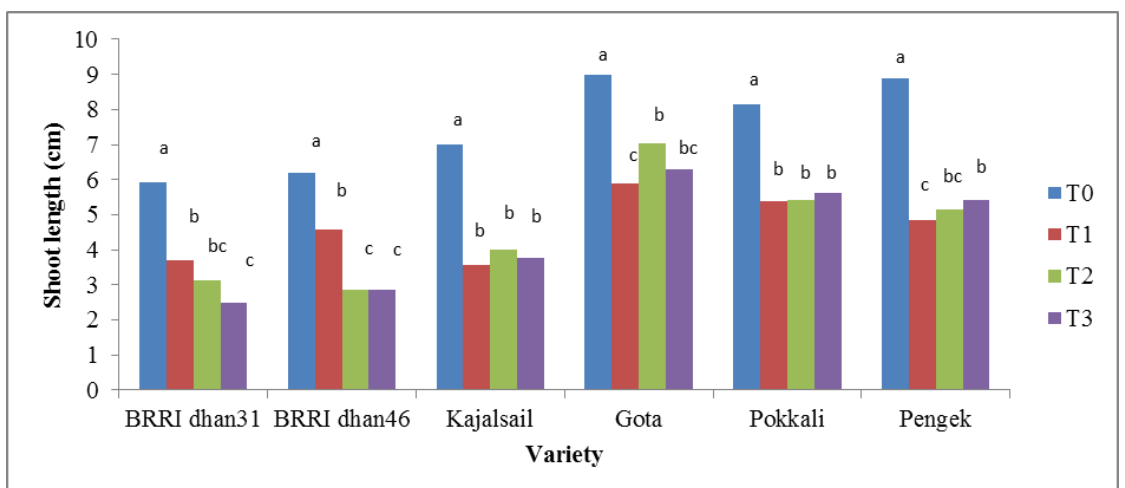

Figure 1. MeJA-induced changes in shoot length of salt stressed rice varieties at $9^{\text {th }}$ day. Significant differences in the treatments are shown with different letters $(p<0.01)$. 


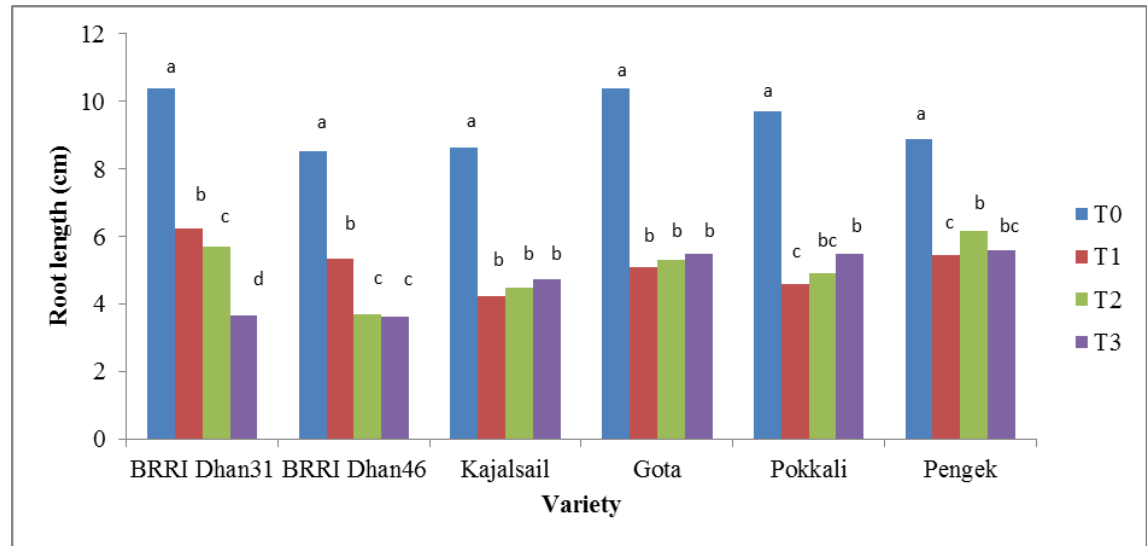

Figure 2. MeJA-induced changes in root length of salt stressed rice varieties at $9^{\text {th }}$ day. Significant differences in the treatments are shown with different letters $(p<0.01)$.
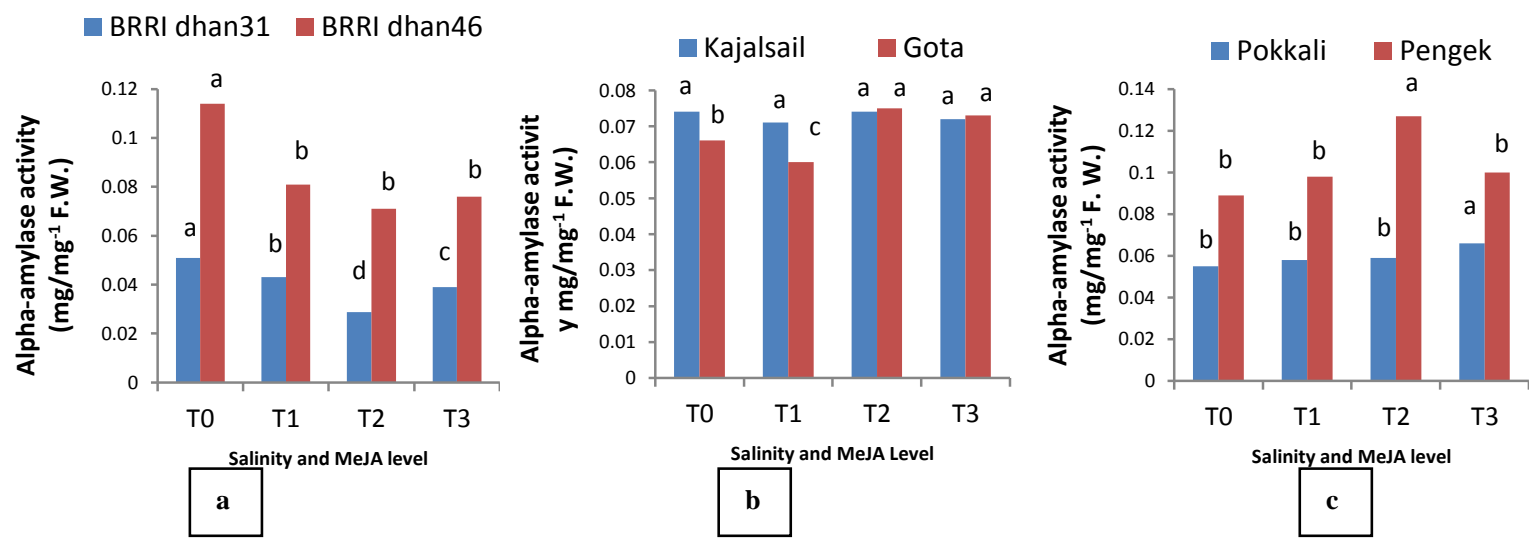

Figure 3. MeJA-induced changes in alpha-amylase activity of salt stressed a) susceptible, b) moderately tolerant, c) tolerant varieties. Significant differences in the treatments are shown with different letters (p $<0.01$ ).

\subsection{Fresh and dry weight of root}

Like shoot wt., all the varieties had significant reduction of both fresh and dry wt. of root on applying salt stress (Table 3). The reduction rate ranged from $28.87 \%$ to $79.37 \%$ in case of fresh wt. while $43.75 \%$ to $74.36 \%$ of dry wt. On applying MeJA, except susceptible varieties both moderately tolerant and tolerant varieties had increased and this rate ranged from $0 \%$ to $107.7 \%$ in case of fresh wt. while $9.09 \%$ to $92.84 \%$ of dry wt. compared to saline condition. Better performance was shown by Pengek in case of fresh wt. on applying $10 \mu \mathrm{M} \mathrm{MeJA}$ whereas $20 \mu \mathrm{M}$ in case of dry wt.

\subsection{Alpha-amylase activity}

In germinated rice seed (control, $\mathrm{T}_{0}$ ), alpha-amylase activity varied from 0.051 to $0.114 \mathrm{mg} \mathrm{mal} . / \mathrm{mg}$ tissue and under saline stress $\left(\mathrm{T}_{1}\right)$, the activity ranged from 0.043 to $0.098 \mathrm{mg}$ mal. / mg tissue (Figure 3). At $12 \mathrm{dSm}^{-1}$ salinity, susceptible and moderately tolerant varieties showed significant reduction while tolerant varieties showed increase in alpha amylase activity.

Upon applying MeJA, negative effect on alpha-amylase activity was observed in the susceptible varieties. In BRRI dhan31, reduction of $3326 \%$ and $930 \%$ were observed under $10 \mu \mathrm{M}$ and $20 \mu \mathrm{M}$ MeJA treated plants respectively while $12.35 \%$ and $6.17 \%$ reduction occurred in BRRI dhan 46 plants. In moderately tolerant varieties, both the varieties showed positive effects upon applying MeJA. In Kajalsail, $422 \%$ and 1.41\% while in Gota $25.0 \%$ and $21.67 \%$ increase in alpha-amylase activity was observed when $10 \mu \mathrm{M}$ and $20 \mu \mathrm{M} \mathrm{MeJA}$ were applied in saline stressed rice seedlings. In tolerant varieties, salt stress increased the alpha-amylase activity which was further enhanced by MeJA application. However, no dose dependent enhancement in alpha-amylase activity was found. In Pokkali, an increment of $1.72 \%$ and $13.79 \%$ while in Pengek $29.59 \%$ and 2.04\% increment was observed in $10 \mu \mathrm{M}$ and $20 \mu \mathrm{M}$ MeJA treated plants respectively. 


\section{Discussion}

Salinity did not produce any noticeable change in the \%GE. As a result a substantial positive effect of MeJA against saline stress was hard to ascertain. Nevertheless, MeJA showed a positive effect on \%GE at $10 \mu \mathrm{M}$ MeJA on $4^{\text {th }}$ day except in BRRI dhan46. Application of $20 \mu \mathrm{M}$ MeJA often demonstrated negative effect. The present study shows that the germination percentage slightly decreased in most of the varieties due to induced salinity. The finding is in line with those of Anbumalarmathi and Mehta (2013); Mondal et al. (2015) and Kumar et al. (2012). Kapoor (2011) also reported that Oryza sativa showed significant reduction in seed germination with $100 \mathrm{mM} \mathrm{NaCl}$ concentration in comparison to control. Upon applying MeJA, dual effect occurred in present study which is also supported by Jin-Hua et al. (2007). In susceptible varieties, increased level of MeJA reduces the \%GE which is also supported by Hasibi et al. (2008) and Norastehnia et al. (2007). The present study also revealed that low concentration of MeJA increases \%GE which is also supported by JinHua et al. (2007) and Enteshar and Jafari (2013).

The present study shows that applying salt stress at germination stage reduced the shoot and root length of all the varieties which is also supported by Mondal et al. (2015); Ologundudu et al. (2014) and Abbas et al. (2013). Pre-soaking maize grains with MeJA led to increase in shoot and root length and counteracted the negative effects of $\mathrm{NaCl}$ stress on plant (Rezai et al., 2013; Abdelgawad et al., 2014; Yoon et al., 2009). Inhibitory effect also showed by some varieties upon MeJA application which also supported by Enteshar and Jafari (2013). The findings are matching well with result of present study where external use of MeJA counteracted the inhibitory effect of salt stress on shoot length. However, this was true for moderately tolerant and tolerant varieties. In susceptible varieties, MeJA couldn't restrain the inhibitory effect of salt stress.

Hussain et al. (2013); Mondal et al. (2015) and Shereen et al. (2007) reported that applying salinity resulted in reduction in fresh and dry weight of both shoot and root of rice seedlings which are in line with the present work as in susceptible varieties. Upon applying methyl jasmonate, fresh and dry weight increased in moderately tolerant and tolerant varieties which were also mentioned by Rezai et al. (2013) and Abdelgawad et al. (2014).

The present study shows that alpha-amylase activity in the germinating seeds was reduced significantly due to salt stress which is also mentioned by Ben Dkhil and Denden (2010). Singh (2004) stated that higher activities of amylase was observed in tolerant varieties than in susceptible varieties which is also in line with the present work where tolerant varieties showed increase in alpha-amylase activity. Upon applying MeJA, decreasing activity of alpha amylase in susceptible varieties was recorded which was also supported by Bialecka and Kepczynski (2003) and Jin-Hua et al. (2007. Positive effect of MeJA to increase the alpha-amylase activity in salt stressed tolerant plants might be a plausible reason to survive those plants in salinity.

\section{Conclusions}

Facts on alpha-amylase activity and growth parameters support the positive effect of MeJA in alleviating saline stress. External use of MeJA in seedling and reproductive stages deserves due attention to counteract the threat from salinity.

\section{Conflict of interest}

None to declare.

\section{References}

Abbas MK, SA Ali, HH Hasan and RH Ghal, 2013. Salt tolerance study of six cultivars of rice (Oryza sativa 1.) during germination and early seedling growth. Journal of Agricultural Science, 5: 250-259.

Abdelgawad ZA, AA Khalafaallah and MM Abdallah, 2014. Impact of methyl jasmonate on antioxidant activity and some biochemical aspects of maize plant grown under water stress condition. Agricultural Sciences, 5: 1077-1088.

Anbumalarmathi $\mathbf{J}$ and P Mehta, 2013. Effect of salt stress on germination of indica rice varieties. eJournal of Biological Sciences, 6: 1-6.

Ben Dkhil B and D Mounir, 2010. Salt stress induced changes in germination, sugars, starch and enzyme of carbohydrate metabolism in Abelmoschus esculentus (L.) Moench seeds. African Journal of Agricultural Research, 5: 408-415.

Bernfeld P, 1955. Alpha and beta amylases. In: Methods in Enzymology, Volume 1, pp. 149-158.

Bialecka B and J Kepczynski, 2003. Regulation of $\alpha$-amylase activitiy in Amaranthus caudatus seeds by methyl jasmonate, gibberellin A3, benzyladenine and ethylene. Plant Growth Regulation, 39: 51-56.

Chen PW, CM Chiang, TH Tseng and SM Yu, 2006. Interaction between rice MYBGA and the gibberellin response element controls tissue-specific sugar sensitivity of $\alpha$-amylase genes. The Plant Cell, 18: 23262340. 
Creelman RA and MV Rao, 2002. The oxylipin pathway in Arabidopsis. In CR Somervile, EM Meyerowitz, Eds, The Arabidopsis Book., American Society of Plant Biologists, USA

Ding CK, Wang CY, Gross KC and Smith DL, 2002. Jasmonate and Salicylate Induce the Expression of Pathogenesis-Related-Proteins Genes and Increase Resistance to Chilling Injury in Tomato Fruit. Planta, 214: 895-901.

Enteshari S and T Jafari, 2013. The effects of methyl jasmonate and salinity on germination and seedling growth in Ocimum basilicum L. Iranian Journal of Plant Physiology, 3: 749-756.

Hasibi N, M Kalantari, M Mazaheri and ME Ahmadi, 2008. The effects of methyl jasmonate, ethylene and their interaction on seed germination and some chemical parameters of canola (Brassica napus L.) seedling. Iranian Journal of Biology, 1(1).

Hussain M, H Park, M Farooq, K Jabran and D Lee, 2013. Morphological and physiological basis of salt resistance in different rice genotypes. International Journal of Agriculture \& Biology, 15: 113-118.

Jin-Hua B, H Sheng-Qin, H Shu-Chun, H Li-Hong and P Rui-Chi, 2007. Effect of Methyl Jasmonate on the germination and the degradation of storage reserve in rice seed. Acta Botanica Sinica, 43: 578-585.

Kang DJ, YJ Seo, JD Lee, R Ishii, KU Kim, DH Shin, SK Park, SW Jang and IJ Lee, 2005. Jasmonic acid differentially affects growth, ion uptake and abscisic acid concentration in salt tolerant and salt-sensitive rice cultivars. J. Agron. Crop Sci., 191: 273-282.

Kapoor RT, 2011. Salinity-induced changes in germination, biomass and physiological characteristics of Oryza sativa L. Paper presented at the international conference on advances in biotechnology and pharmaceutical sciences (ICABPS 2011), Dec 2011, Bangkok.

Khan MSA, A Hamid and MA Karim, 1997. Effect of sodium chloride on germination and seedling characters of different types of rice (Oryza sativa L.). J. Agron. Crop Sci., 179: 163-169.

Kumar R, MP Singh and S Kumar, 2012. Effect of salinity on germination, growth, yield and yield attributes of wheat. International Journal of Scientific \& Technology Research, 1: 19-23.

Lutts S, JM Kinet and J Bouharmont, 1995. Changes in plant response to $\mathrm{NaCl}$ during development of rice (Oryza sativus L.) varieties differing in salinity resistance. J. Exp. Bot., 46: 1843-1852.

Mondal P, RN Remme, D Das, Y Ali and E Kabir, 2015. Germination and seedling growth of indigenous Aman rice under $\mathrm{NaCl}$ salinity. International Journal of Multidisciplinary Research and Development, 2: 251-257.

Norastehnia A, RH Sajedi and M Nojavan-Asghari, 2007. Inhibitory effects of methyl jasmonate on seed germination in maize (Zea mays): effect on $\alpha$-amylase activity and ethylene production. Gen. Appl. Plant Physiology, 33: 13-23.

Ologundudu AF, AA Adelusi and RO Akinwale, 2014. Effect of salt stress on germination and growth parameters of rice (Oryza sativa L.). Not. Sci. Biol., 6: 237-243.

Prado FE, JA Gonzalez, C Boero, M Gallardo, C Boero and A Kortsarz, 1995. Changes in soluble carbohydrates and invertase activity in Chenopodium quinoa developed for saline stress during germination. Cur. Top. Phytochem., 14: 15.

Rezai S, M Orojloo, SS Bidabadi and M Soleimanzadeh, 2013. Possible role of methyl jasmonate in protection to Nacl - induced salt stress in pepper cv. "Green Hashemi". Intl. J. Agri. Crop Sci., 6: 1235-1238.

Sharmin S, 2012. Saline induced changes in growth parameters, enzymatic activity and free amino acid content of rice (Oryza sativa) plant. MS thesis, Bangladesh Agricultural University, Bangladesh.

Shereen A, RU Ansari, S Yasmin, S Raza, S Mumtaz, MA Khan and SM Mujtaba, 2007. Physiological responses of rice (Oryza sativa L.) to saline stress. Pak. J. Bot., 39: 2527-2534.

Singh AK, 2004. The physiology of salt tolerance in four genotypes of chickpea during germination. Journal of Agricultural Science and Technology, 6: 87-93.

Tsonev TD, GN Lazova, ZG Stoinova and LP Popova, 1998. A possible role for jasmonic acid in adaptation of barley seedlings to salinity stress. J. Plant Growth Regul., 17: 153-159.

Walia H, C Wilson, P Condamine, X Liu, AM Ismail and TJ Close, 2007. Large-Scale Expression Profiling and Physiological Characterization of Jasmonic Acid-Mediated Adaptation of Barley to Salinity Stress. Plant, Cell \&Environment, 30: 410-421.

Wasternack C and B Hause, 2002. Jasmonates and octadecanoids: signals in plant stress responses and development. Prog. Nucleic Acid Res. Mol. Biol., 72: 165-221.

Yeo AR, 1999. Predicting the interaction between the effects of salinity and climate change on crop plants. Sci. Hortic., 78: 159-174.

Yoon JY, M Hamayun, S Lee and I Lee, 2009. Methyl jasmonate alleviated salinity stress in soybean. J. Crop Sci. Biotech., 12: 63 - 68. 